\title{
PRIVATE - PUBLIC DIALOGUE TO IMPROVE BUSINESS ENVIRONMENT
}

\section{Introduction}

The Republic of Moldova increasingly recognizes that high-quality regulation at the national and regional level is an essential precondition for the effective response to a range of fundamental trends of the country: legislative harmonization with acquits communitarian of the European Union, increased competition, decreased state aid transfers, increased global trade, domestic private sector development, SME promotion, regional and environmental policies, enhancement of social and labor market policies, improved investment climate, etc. An important element to improve the quality of regulatory policies is that the state should elaborate and adopt new policies and normative acts as well as create a new institutional framework based on its efficient activities.

However, this is not sufficient - new capacities need to be implemented and enforced; only then ultimately delivered results will be deemed successful. The political will need to be tested in the face of social opposition, especially from private interests. The institutions need to have human and financial resources necessary to apply appropriate policies and create necessary tools. The second stage of testing focuses on the policy and the question whether the inputs have produced regulations of a better quality. Finally, the institutional framework needs to implement and enforce the tools to achieve specific results for individuals and businesses. These would lead to positive consequences related to an increased amount of investments, economic growth, better environment and welfare, etc.

\section{Regulatory Reform's objectives}

The essence of the regulatory reform provided in the Republic of Moldova consists of a well-balanced approach of drafting and implementing regulations. Such 
a balance is reached by analyzing the problem, possible solutions and interests of all parties that will be impacted by new regulations - the State, business and the general public. A regulatory impact analysis may lead to a conclusion that there is no need for adopting a new regulation, and if existing normative acts are inefficient, then adopting a new one requires identification of costs, benefits and impact for the State, individuals and business. The necessity to give up most of the existing regulations and elaborate a new foundation might be crystallized after the regulatory impact analysis. This new foundation will also serve as a starting point for the transition period until the creation of an adequate legal and institutional framework.

Taking into account the realities of the Republic of Moldova, the main objective of the regulatory reform is the substantive decrease of entrepreneurial dependence on excessive administrative regulations, reduction of financial and time costs run by entrepreneurs spent on opening and maintaining business, which requires obtaining licenses, authorizations and permissions. The expenditures are paid for services provided by bodies having supervising and inspection authority. The ultimate goal of the regulatory reform is the development of new state policies. It includes elaboration of new norms as well as development of new regulatory mechanisms based on the regulatory impact analysis. The new legal and institutional framework shall be subject to an efficient state supervision for the fructification of expected results.

It has to be mentioned that in order to ensure efficiency of new policies implementation, media coverage shall be a must in order to reflect the public opinion. This approach is of a psychological nature as well - participation of the large public, especially of business representatives, gives confidence that the regulation is their own product. Therefore the chances that new regulations will be observed are increasing whereas requests for modifications will not be submitted.

Being a complex process, the regulatory reform includes the institutional reform as an indispensable element. In this context, it is intended to revise the structures, functions, and procedures in the activity of certain ministries and departments as well as other bodies, which have a role to play in the elaboration of state policy regarding the entrepreneurial activity. Motivation of public authorities as well as the trend to modify their approach in dealing with entrepreneurs is of the utmost importance. As to the legal framework, the regulatory reform establishes top priorities in the economic and political agenda:

1. Improvement and optimization of the activity of authorities with inspection and supervising functions, including:

- elaboration and implementation of a single law framework concerning control and inspections; 
- modification based on the above law of all normative acts in the field;

- optimization of the State control and supervision system;

- optimization of numbers of non-fiscal controls;

- creation of an automatic informational system for evidence of supervision and control activities (State Register).

2. Streamlining of paid services to economic agents having as objective:

- avoidance of the conflict of interests;

- elimination of excessive services;

- assurance of loyal competition regarding paid services provision;

- optimization of paid services based on the market economy;

- facilitation and minimization of the costs of doing business.

3. Optimization of the authorization system for company start-ups and continuing operations resulting in:

- combining more procedures (registration, authorization, licensing, etc) in one single process One Stop Office;

- analyzing the necessities and establishing criteria for obtaining licenses, authorizations, permissions and respective costs;

- restriction of authorized system by obtaining activity license;

- reducing practices allowing the possibility to obtain double licenses based on other permissions or authorization documents;

- minimizing costs and time supported by entrepreneurs for obtaining licenses, authorizations, permissions.

\section{Competitiveness Enhancement and Enterprise Development project role in the Regulatory Reform Process}

The overall objective of the Competitiveness Enhancement and Enterprise Development (CEED) USAID project is to create a business environment and investment climate that stimulates, supports and rewards competitive enterprise performance. This objective can be implemented by accelerating the business environment improvement process in the three CEED target sectors, focusing on those initiatives that will stimulate competitive economic growth, promote increased exports and attract investment (foreign or domestic). For this purpose CEED started to build strong working relationships with key private and public sector stakeholders 
gaining a place in the business environment improvement process. This aim came after the discussion with private companies. Talking to private companies' owners and managers you would encounter the same complaint - they are not "heard" by the public sector. Their proposals on better conditions for business development expressed at the meetings with governmental bodies' representatives were always left aside. As a result, entrepreneurs were left to solve their problems alone, while the public sector representatives remained with their vision unchanged. It led to low level of trust on part of entrepreneurs in interventions or proposals to change the situation and contribute to business environment improvement, and growing dissatisfaction with current state of affairs.

USAID project came up with a series of initiatives to improve the situation to enable the effective public-private dialogue in Moldova. The suggested mechanisms including focus groups, task forces and company attachments provided trustful and respectful environment to discuss and share ideas. The initiated activities went in line with the newly adopted Law on basic principles regulating entrepreneurial activity, No. 235-XVI as of July 20, 2006, so called "guillotine process".

In order to assist public sector reforms in the first year of the activity, CEED investigated existing legal and regulatory impediments and barriers which limit business growth and competitiveness in its target sectors, particularly those which affect the operational, trade and investment activities of companies. CEED began this activity by analyzing existing assessments and reports and discussing with leading businesses, associations and key representatives from the three target sectors the regulatory business environment in Moldova and the legal and regulatory environment impediments that are preventing the growth of CEED's target sectors. To obtain an independent opinion of the private sector's view of business environment constraints and imperfections, as well as to validate findings revealed during the initial desk research and discussions with private sector, CEED conducted focus group research in each of the three target sectors. As a result, CEED has developed a list of the industry-specific legal and regulatory impediments, which presents a common voice and opinion of businesses in those sectors. This document served as a starting point for initiating business environment improvement actions and developing further dialogue between the public and private sector.

The key task of the project assistance refers to complementing and providing input into the regulatory reform process articulated in Law on basic principles regulating entrepreneurial activity. This law calls on all specialized central bodies of public administration and the unsubordinated administrative authorities of the Government to complete an inventory of all relevant laws and regulations under their review, to recommend to the State Commission for regulating entrepreneurial activity those that require modifications or amendments, and thereafter to take 
measures to introduce the necessary reforms to the State Commission for referral to the Parliament for adoption.

CEED project decided to focus attention on the public-private dialogue effectiveness improvement by strengthening the capacity of leading industry associations to advocate effectively for the interests of their constituents. Strengthening key associations and other organizational partners such as task forces, one for each sector, composed of 7-10 interested parties from the private and public sectors, ensured that business has the institutional framework to expand, grow and remain an effective advocate for enterprise partners.

The first step of joint work with public sector bodies (Ministry of Industry, Ministry of Information Development and Moldova Vin Agency, see figure below) on the recommendations provided by private sector in order to prove them and assist drafting recommendations initiatives to State Commission for regulating entrepreneurial activity. 
Figure 1. The mechanism of the Regulatory Reform process

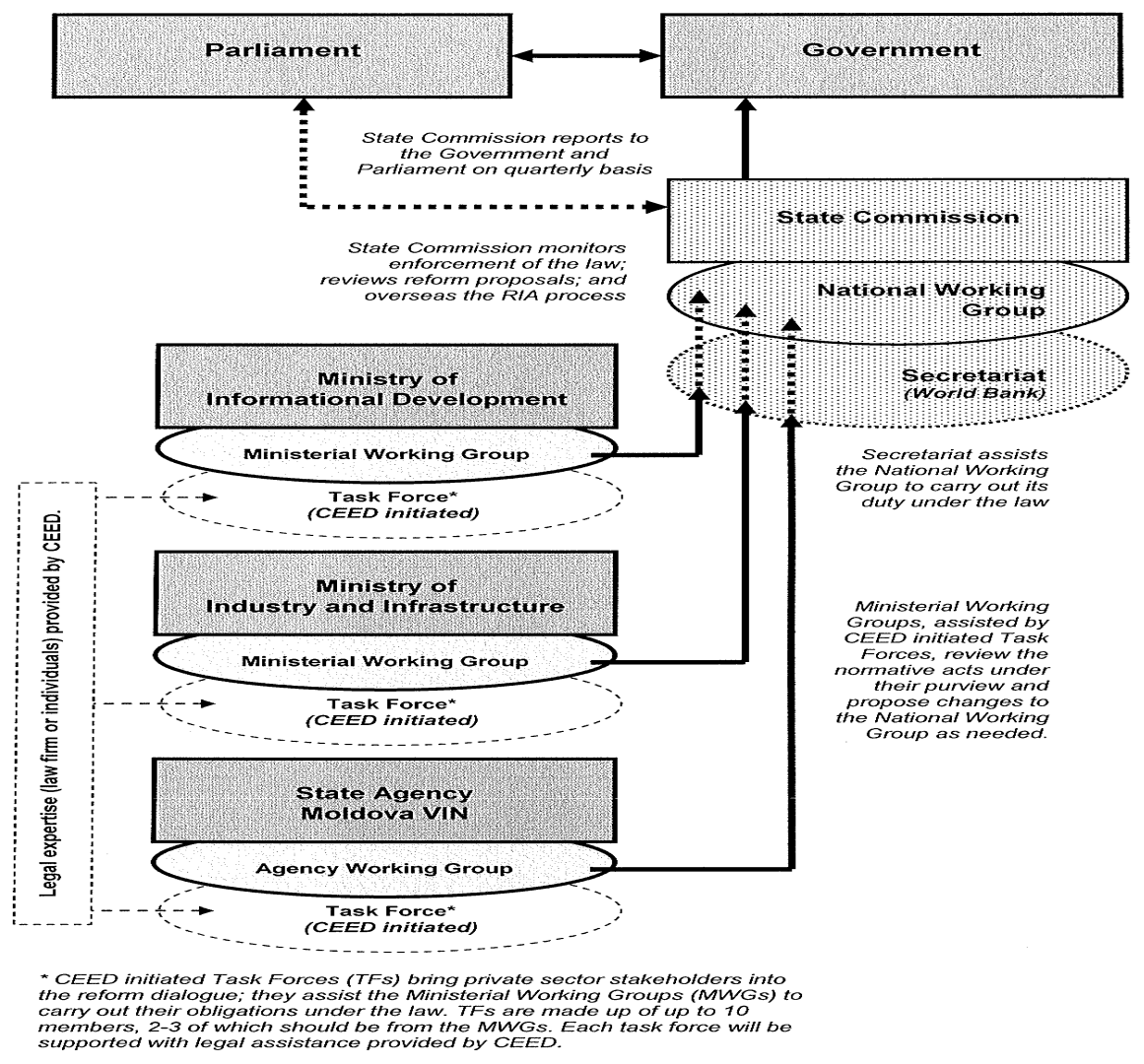

These activities were in line with Article 20, mechanism of review of normative acts of Law on basic principles regulating entrepreneurial activity No. 235-XVI as of 20/07/2006. During September - December 2006 the Task Force members assisted the sector Ministries and Agency to draft modifications and amendments to the normative acts in their area of activity in compliance with nominated law and according with the list of priorities for modifications proposed by Private Sector.

The second step was dedicated to the presentation of the Reform Proposals to all cluster representatives in an open forum. This event had the purpose to expose in media the recommendations proposed for the whole sector/cluster members and industry stakeholders and get their feedback on the proposals made. Also at this stage, the Reform Proposals were approved for submitting to the State Commission for regulating entrepreneurial activity for consideration. To this moment the 
authorities submitted to the State Commission drafts and information notes for review, and concomitantly presented to the Parliament a report on the review results of normative acts at the respective stage.

As third step the Task Forces members worked with the State Commission and Secretariat organized by the Ministry of Economy and Trade to validate issue reviews and asses the regulatory impact of draft normative acts on the sector competitiveness and growth. Finally, after this process, the Task Force members worked with public sector bodies to accomplish the final draft and information notes based on the Commission's review.

Today, when indigenous companies strive to compete locally with international companies, one of the key strengths these companies ought to acquire and capitalize in order to survive is the ability to advocate their interests. In lobby and advocacy process it is important to establish a transparent and open dialogue between the Parliament \& Government and Business \& Civil Society. From our recent experience in facilitating this dialogue, there emerged a concerning fact that local NGOs are not ready to take advantage of the openness of Moldovan Parliament proposed to the civil and business society by adopting the Concept of Cooperation between the Parliament and Civil Society.

Following this opportunity, when the draft of the proposed modifications was submitted to the Moldovan Parliament, it was decided to use the opportunity provided by the International Business Association Business Parliament (IABP), one of the CEED project partner. The IABP offers an internationally recognized protocol aimed at enhancing the relationship between MPs and business community in a transparent and non-corrupt way, informing legislative process. This collaboration results in a dialogue, which helps identify the needs of the business community for the purpose of developing legislation and policies, which achieve maximum benefit and have minimal unintended consequences.

All three industries, ICT, apparel and wine legal frameworks as well as Law on basic principles regulating entrepreneurial activity No. 235-XVI are very complex, therefore it is pivotal for MPs to get an in-depth understanding of key regulatory issues of the proposed modifications and respective industries legal frameworks so that better informed public policies are developed and eventual negative consequences are minimized or eliminated.

CEED and IABP assisted the organization of the so-called "company attachments" activity, which has the goal to assist an in-depth understanding of a particular aspect of the business sector. The company attachment program was tailored to the needs of the MP and used the learning through involvement approach. The scope of this program lied within the broader regulatory framework of the mentioned Law and aimed at informing MPs about the challenges ICT, apparel 
and wine industries currently face. Company attachments give Members of the Parliament an opportunity to learn more about a particular industry by pairing them with a willing business for a period of time in order to understand the practical concerns faced by the businesses.

The event started with company visit, then the MPs and representatives of the top management discussed the key topics addressed in the Draft of the Laws modification and on the impact of these issues on company business. Members of the Parliament had an opportunity to see the impact of their decisions on business. Company attachments helped both parties know more about each other and speed up the process of improving the business environment. The challenges concern various issues that were approached in the set of the proposed modifications starting from licensing down to the specific issues that are critical for companies, and the regulators were discussed with three companies per one from each sector that hosted the MPs.

\section{Results}

In result of the Competitiveness Enhancement and Enterprise Development assistance, all 37 legislative initiatives, jointly developed by public-private sectors representatives, were approved by the Parliament, and consequently led to the modification of 11 laws and normative acts. As an effect, the activity of software developers does not require licensing, and a number of conditions for getting it have become significantly decreased for winemakers. The latter also benefited from the simplified grapes suppliers declaration and producers' registration documents. Entrepreneurship regulation functions are now separated from the control ones in all sectors of Moldovan economy. The constructive dialogue established by USAID enabled the private sector to have a stronger and more effective voice in business environment improvement. "It is for the first time that managers were involved directly and their opinions were not only listened to, but also introduced in the proposals on the legislative framework modification," comments the Association of Light Industry (APIUS) President. 


\section{Streszczenie}

Jednym z celów działań Amerykańskiej Agencji do Spraw Rozwoju Międzynarodowego na rzecz Mołdawii (projekt USAID/Moładawia) jest wsparcie politycznych i prawnych reform w tym kraju. Wstępna ocena dokonana przez przedstawicieli Agencji wskazała, że przemysł stoi przed wieloma prawnymi barierami, włączając w to ograniczenia sektorowe. Należy zauważyć, że rząd Mołdawii został już zobowiązany przez OECD do wsparcia przedsiębiorczości w ramach programu „Regulatory Reform”, jednakże niekoniecznie objął on całe środowisko biznesowe. Dlatego też dla wsparcia całego sektora prywatnego Agencja zaproponowała usprawnić działania rządu w tym zakresie, które są realizowane w ramach ,procesu Guillotine".

Niniejszy artykuł przedstawia proces reform legislacyjnych w Mołdawii, zarówno na poziomie centralnym jak i samorządowym w odniesieniu do rozwoju całego środowiska biznesowego. 